CATALLAXY

Volume 3 Issue 2 December 2018

e-ISSN 2544-090X

¿ www.catallaxy.pl

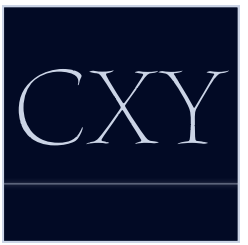

Oryginalny artykut naukowy

otrzymano: 11.05.2018 / zaakceptowano: 25.06.2018 / opublikowano online: 30.06 .2018

Ravinskij, D. (2018). Synchronizacja cykli koniunkturalnych wybranych państw byłej Jugosławii ze strefą euro. Catallaxy, 3(2): 89-101. doi:10.24136/cxy.2018.004.

\title{
Synchronizacja cykli koniunkturalnych wybranych państw byłej Jugosławii ze strefą euro
}

\author{
DANIEL RAVINSKIJ \\ Szkoła Gtówna Handlowa w Warszawie, al. Niepodległości 162, 02-554 Warszawa, Polska \\ $\mathbf{\square}$ daniel.rawinski@gmail.com \\ (D) orcid.org/0000-0002-3890-6532
}

\begin{abstract}
Abstrakt
Motywacja: Zgodnie z teorią optymalnych obszarów walutowych R. Mundella, synchronizacja cykli koniunkturalnych jest niezbędna dla uczestników strefy walutowej. Kryterium to nie jest wymienione w formalnych wymaganiach przystąpienia państw członkowskich Unii Europejskiej (UE) do strefy euro, więc jest często pomijane w analizie przygotowań państw członkowskich do przyjęcia wspólnej waluty.

Cel: Celem niniejszego artykułu jest analiza stopnia synchronizacji koniunktury czterech państw byłej Jugosławii z koniunkturą strefy euro. Państwa byłej Jugosławii są na różnym etapie integracji europejskiej i konwergencji z gospodarką unijną, więc stopień synchronizacji cykli koniunkturalnych między państwami również jest inny.

Materiały i metody: W niniejszym artykule użyto szeregi czasowe PKB i produkcji przemysłowej strefy euro i czterech państw byłej Jugosławii (Słowenii, Chorwacji, Serbii i Macedonii), które zdekomponowano używając dwukrotnie filtru górnoprzepustowego Hodricka-Prescotta. Następnie zidentyfikowano cykle klasyczne, cykle odchyleń i punkty zwrotne, które były podstawą analizy synchronizacji cykli.

Wyniki: Wśród analizowanych państw byłej Jugosławii, gospodarka Słowenii jest dobrze zsynchronizowana z gospodarką strefy euro. W przypadku Chorwacji wystąpiła słaba synchronizacja w kategorii produkcji przemysłowej. W przypadku Serbii i Macedonii wykazano dość słabą synchronizację w każdej kategorii, zwłaszcza PKB, na co wskazywał niższy poziom współczynnika korelacji oraz dodatkowe cykle koniunkturalne.
\end{abstract}

Stowa kluczowe: strefa euro; cykle koniunkturalne; Batkany

JEL: E32; FO2

1. Wprowadzenie

Państwa byłej Jugosławii cechuje duża różnica stopnia integracji z Unią Europejską (UE). Słowenia została członkiem UE w 2004 roku i jako pierwsza, spośród państw postsocjalistycznych, wprowadziła euro. Chorwacja została członkiem UE w 2013 roku. Pozostałe państwa są na różnych etapach wejścia do UE.
Zgodnie $z$ Traktatem o Unii Europejskiej (TUE, 1992), państwa członkowskie są zobowiązane do wprowadzenia euro po spełnieniu określonych kryteriów. Dążące do członkostwa w UE państwa byłej Jugosławii muszą się zmierzyć z tym, że będą musiały wprowadzić wspólną, europejską walutę.

Wymienione w TUE (1992), kryteria nie zawierają bezpośredniego wymagania wysokiej synchronizacji koniunktury państwa 
przystępującego do strefy euro z koniunkturą strefy euro. Znaczenie takiego wymagania wynika $z$ teorii optymalnych obszarów walutowych (Mundell, 1961), która zakłada m.in. wysoki stopień synchronizacji cykli koniunkturalnych regionów tego obszaru (Frankel i Rose, 1998). Państwa, które zrzekają się własnej polityki monetarnej na rzecz wspólnej dla obszaru walutowego, muszą mieć zsynchronizowane zmiany aktywności gospodarczej. W przeciwnym przypadku, polityka monetarna działająca na rzecz części obszaru, będzie sprzeczna $z$ interesami innej części obszaru walutowego.

Celem niniejszego artykułu jest analiza stopnia synchronizacji koniunktury czterech państw byłej Jugosławii: Słowenii, Chorwacji, Serbii oraz Macedonii $z$ koniunkturą strefy euro. Pozwoli ona na ocenę możliwości przeniesienia przyszłych szoków w strefie euro do Słowenii oraz gotowości wejścia do strefy euro przez Chorwację, Serbię i Macedonię.

W tym celu użyto szeregów czasowych PKB oraz produkcji przemysłowej $\mathrm{w}$ analizowanych państwach. Zdekomponowano je, zidentyfikowano punkty zwrotne $\mathrm{w}$ cyklach koniunkturalnych $w$ ujęciu klasycznym oraz ujęciu cyklu odchyleń. Wyodrębnione cykle zbadano morfologicznie oraz pod względem korelacji między wahaniami odchyleń wartości szeregów a trendem długookresowym.

W sekcji 2. przedstawiono przegląd literatury na temat synchronizacji cykli koniunkturalnych oraz podsumowano dotychczasowe badania w tym zakresie dla państw byłej Jugosławii. W sekcji 3. przedstawiono wykorzystaną metodę badawczą, a w sekcji 4 . wyniki analizy. Sekcja 5. stanowi podsumowanie otrzymanych wyników.

\section{Przegląd literatury}

Kluczowy wkład do badań cykli koniunkturalnych wnieśli A.F. Burns i W.C. Mitchell (1946). Przedstawili oni klasyczną definicję cyklu koniunkturalnego jako „rodzaju fluktuacji w zagregowanej aktywności gospodarczej państw organizujących swoją działalność głównie w przedsiębiorstwach prywatnych".
Zajęli się oni też identyfikacją punktów zwrotnych gospodarki USA.

I. Mintz (1970), wprowadziła do ekonomii pojęcie cyklu odchyleń - cyklicznych wahań odchyleń wartości zmiennych od długookresowego trendu rosnącego. Jako pierwsza użyła też procedury opracowanej przez $G$. Bry'a i C. Boschan do obiektywnej identyfikacji punktów zwrotnych cykli koniunkturalnych.

Ekonomiści zajmujący się badaniem cykli koniunkturalnych podjęli próby odnalezienia punktów zwrotnych, wspólnych dla całej strefy euro lub UE. M. Artis i in. (2004), zidentyfikowali punkty zwrotne, wspólne dla całej strefy euro i sprawdzili, jaka jest reakcja poszczególnych państw członkowskich na wahania cykliczne.

J. de Haan i in. (2008), doszli do wniosku, że synchronizacja cykli koniunkturalnych państw strefy euro zmienia się w czasie, jednak na końcu XX wieku synchronizacja poprawiła się.

A. Seymen (2012), udowodnit, że różnice w cyklach koniunkturalnych poszczególnych państw strefy euro nie wynikają $z$ różnych reakcji na szoki zewnętrzne, ale $z$ asymetrycznych szoków wewnątrz tych gospodarek.

P. Gogas (2013), badając cykle koniunkturalne państw UE w latach 1989-2010, doszedł do wniosku, że wprowadzenie euro przyczyniło się do synchronizacji cykli koniunkturalnych wewnątrz strefy euro.

D. Giannone i in. (2009), nie odnaleźli zmian w cykliczności poszczególnych gospodarek strefy euro po zmianie waluty w kierunku homogeniczności cykli. Te, które były bardziej zmienne, takimi też pozostały.

Literatura dotycząca cykli koniunkturalnych $w$ państwach byłej Jugosławii nie jest liczna. Prawdopodobnie wynika to $z$ braku zainteresowania ekonomistów spoza tych państw koniunkturą regionu będącego na peryferiach Europy i nieposiadającego silnych gospodarek. Innym powodem może być brak dostępu do wiarygodnych i wystarczająco długich szeregów czasowych dla analizowanych zmiennych. Ponadto, problemy niepowiązane $z$ gospodarką i niebędące przedmiotem zainteresowania ekonomii, $z$ którymi borykają się 
te państwa, często są ważniejsze od problemów stricte gospodarczych. To z kolei jeszcze bardziej zmniejsza zainteresowanie ekonomistów koniunkturą państw byłej Jugosławii.

Prace analizujące kilka państw regionu należą do rzadkości. W jednym $z$ niewielu przykładów takich prac, S. Obradović i V. Mihajlović (2013), zastosowali podwójny filtr Hodricka-Prescotta do estymacji składnika cyklicznego, ale nie analizowali Macedonii, a do kategorii strefy euro zaliczono tylko piętnaście państw. F. Canova i A. Schlaepfer (2015), jako jedni z niewielu ekonomistów, w swojej pracy analizowali cykle koniunkturalne Serbii, Chorwacji, Słowenii i Macedonii. Te państwa zostały przez autorów zaliczone do szerszego regionu śródziemnomorskiego. Ich celem było zbadanie, czy cykle koniunkturalne państw regionu są zsynchronizowane między sobą oraz z państwami UE. Autorzy doszli do wniosku, że koniunktura w regionie jest w bardzo małym stopniu zsynchronizowana.

Jedynym, szeroko analizowanym pod względem wahań koniunkturalnych państwem, spośród omawianych $\mathrm{w}$ niniejszym artykule, jest Słowenia. Przyczyną tego jest to, że Słowenia jest często analizowana w kontekście regionu Europy Środkowo-Wschodniej, nowych członków UE oraz strefy euro. Ponadto, koniunktura słoweńska jest badana przez OECD w ramach barometru koniunktury CLI (composite leading indicators).

Z. Darvas i G. Szapáry (2008), badając synchronizację cykli koniunkturalnych między nowymi a starymi członkami UE, zauważyli, że przed wejściem do UE, Słowenia była jednym $z$ liderów synchronizacji cyklu koniunkturalnego z UE i gospodarka słoweńska była dobrze zsynchronizowana $z$ europejską w kategoriach $\mathrm{PKB}$, przemysłu i eksportu, ale gorzej - w kategoriach konsumpcji i usług.

Używając współczynników konkordancji jako miary synchronizacji cykli koniunkturalnych, R. Jiménez-Rodríguez i in. (2013), uznają Słowenię, Polskę oraz Węgry za najbardziej zsynchronizowane ze strefą euro państwa spośród tych, które przystąpiły w 2004 roku lub później.

\section{Materiały i metody}

W niniejszym artykule użyto danych o PKB oraz produkcji przemysłowej dla czterech analizowanych państw oraz strefy euro $w$ jej obecnym kształcie. Źródłem danych był Eurostat (2018). Szeregi czasowe obejmowały różny okres, w zależności od dostępności danych. Fakt, że Słowenia jest członkiem strefy euro nie stanowił przeszkody dla analizy synchronizacji koniunktury, gdyż słoweńska gospodarka jest tylko małą częścią strefy euro. W 2017 roku PKB Słowenii stanowiło zaledwie 0,39\% PKB strefy euro (Eurostat, 2018).

Do analizy synchronizacji cykli koniunkturalnych w kategorii PKB wykorzystano dane kwartalne, na podstawie których sporządzono indeks jednopodstawowy, w którym poziom równy sto odpowiadał przeciętnej wartości kwartalnego PKB w 2010 roku. W przypadku strefy euro, Serbii oraz Słowenii, dane o PKB obejmują okres od pierwszego kwartału 1995 roku do czwartego kwartału 2017 roku włącznie (dziewięćdziesiąt dwie obserwacje). Szeregi dla Macedonii i Chorwacji obejmują dane od pierwszego kwartału 2000 roku również do ostatniego kwartału 2017 roku (siedemdziesiąt dwie obserwacje). Wszystkie szeregi, oprócz dotyczącego Macedonii, wyrównano sezonowo i kalendarzowo.

W kategorii produkcji przemysłowej, wykorzystano wyrównane sezonowo dane miesięczne o indeksie łącznej produkcji przemysłowej (poziom równy sto odpowiadał przeciętnej wartości w 2010 roku). Punktem końcowym szeregów w tej kategorii był poziom indeksu w grudniu 2017 roku, punkty początkowe były różne. Dane dla strefy euro obejmowały okres od stycznia 1991 roku (324 obserwacje), dla Chorwacji i Słowenii - od stycznia 1998 roku (240 obserwacji), dla Serbii i Macedonii — od stycznia 2000 roku (216 obserwacje).

W analizie i dekompozycji szeregów czasowych przyjęto równanie (1) (Adamowicz $\mathrm{i}$ in., 2012):

$$
Y_{t}=T_{t}+C_{t}+S_{t}+I_{t}
$$


gdzie:

$T_{t}$ - wartość składnika trendu;

$C_{t}$ - składowa obrazująca wahania cykliczne;

$S_{t}$ - składowa obrazująca wahania sezonowe;

$I_{t}$ - składowa obrazująca wahania nieregularne.

W przypadku analizy wahań koniunkturalnych jako zmian w cyklu klasycznym, przedmiotem analizy były zmiany zachodzące $w$ sumie $T_{t}+C_{t}$. $Z$ kolei $w$ analizie wahań odchyleń czynnika cyklicznego od trendu, wykorzystano iloraz $C_{t} / T_{t}$ wyrażający odchylenia składowej cyklicznej od trendu, jako jego część. Wynik ten wyrażał wówczas odchylenie składowej cyklicznej od trendu w procentach.

W celu otrzymania szeregów odpowiednich do analizy zbieżności cyklów koniunkturalnych, przeprowadzono kilkuetapową dekompozycję szeregu $Y_{t}$. W pierwszym etapie usunięto składową wahań sezonowych $S_{t}$. Spośród dziesięciu analizowanych szeregów czasowych, dziewięć w bazie Eurostat (2018), podano jako wyrównane sezonowo i uwzględniające efekt kalendarza. Jeden szereg wyrównano sezonowo używając procedury TRAMO (time series regression with ARIMA noise, missing values and outliers) i SEATS (signal extraction in ARIMA time series) w pełnej konfiguracji (RSA full) i programu JDemetra+.

Następnym krokiem było wyodrębnienie $z$ szeregu odsezonowanego, składowej trendu i rezydualnie sumy składowej sezonowej i wahań nieregularnych. W tym celu używa się filtru pasmowo-przepustowego (np. filtr Christiano-Fitzgeralda lub filtr Baxter-Kinga) lub górno-przepustowego (filtr Hodricka-Prescotta). Różnica między filtrami polega na tym, że przy pomocy filtru pasmowo-przepustowego, możliwe jest oczyszczenie analizowanego szeregu czasowego $z$ wahań niewchodzących w pasmo częstotliwości, wybranych przez badacza (i uzasadnionych empirycznie). Natomiast przy pomocy filtru górno-przepustowego możliwe jest wyeliminowanie wahań o większej częstotliwości niż zadana (Adamowicz i in., 2012).
Do dekompozycji wyrównanego sezonowo szeregu czasowego użyto modyfikacji filtru Hodricka-Prescotta, zmieniającej go na filtr pasmowo-przepustowy. Modyfikacja ta jest używana $w$ pracach OECD nad barometrami CLI, których celem jest wyprzedzenie koniunktury i wskazanie punktów zwrotnych przed ich wystąpieniem (Yamada, 2011). Jest on lepszy niż filtr ChristianoFitzgeralda, jeśli celem badawczym jest raczej identyfikacja punktów zwrotnych, niż większa precyzja numeryczna w pomiarze amplitudy między fazami cyklu koniunkturalnego (Nillson i Gyomai, 2011). Filtr Baxter-Kinga odrzucono, gdyż działa on podobnie do filtru Christiano-Fitzgeralda, ale też „ucina” obserwacje na końcach szeregów (Adamowicz i in., 2012).

Pasmowo-przepustową modyfikację filtru Hodricka-Prescotta zastosowano dwuetapowo. Początkowo, wyrównany sezonowo szereg czasowy zdekomponowano na składową trendu długookresowego (tutaj $\tau_{t}$ ) oraz sumę $C_{t}+I_{t}$. Filtr Hodricka-Prescotta jest rozwiązaniem problemu optymalizacyjnego, wyrażonego wzorem (2):

$$
\min _{\tau_{t}}\left[\begin{array}{l}
\sum_{t=1}^{T}\left(Y_{t}-\tau_{t}\right)^{2}+ \\
+\lambda \sum_{t=2}^{T-1}\left[\left(\tau_{t+1}-\tau_{t}\right)-\left(\tau_{t}-\tau_{t-1}\right)\right]^{2}
\end{array}\right] .
$$

$\mathrm{W}$ drugim etapie, rozdzielono sumę $C_{t}+I_{t}$ na właściwą składową cykliczną $C_{t}$ oraz, niepotrzebne $w$ analizie synchronizacji cykli, wahania nieregularne o wysokiej częstotliwości $I_{t}$. Filtr Hodricka-Prescotta można wówczas opisać równaniem (3):

$$
\min _{C_{t}}\left[\begin{array}{l}
\sum_{t=1}^{T}\left[\left(C_{t}+I_{t}\right)-C_{t}\right]^{2}+ \\
+\lambda \sum_{t=2}^{T-1}\left[\left(C_{t+1}-C_{t}\right)-\left(C_{t}-C_{t-1}\right)\right]^{2}
\end{array}\right] .
$$

Literą $\lambda$ we wzorach (2) i (3) oznaczono parametr wygładzania. Jego poziom zależy od częstotliwości wahań. W niniejszym artykule wykorzystano, używany przez Instytut Rozwoju Gospodarczego Szkoły Głównej Han- 
dlowej (IRG), przedział wahań 1,5-10 lat. Poziom parametru oblicza się według wzorów (4) i (5) (Maravall i del Rio, 2001):

$$
\begin{aligned}
& \lambda=\left[4\left[1-\cos \left(\omega_{0}\right)\right]^{2}\right]^{-1}, \\
& \omega_{0}=\frac{2 \pi}{\tau} .
\end{aligned}
$$

Pierwszym krokiem w analizie morfologicznej była identyfikacja punktów zwrotnych. W tym celu użyto uproszczonej procedury Bry'a-Boschan'a, polegającej na:

- identyfikacji wartości wyższych (dla górnych punktów zwrotnych) oraz niższych (dla dolnych punktów zwrotnych) od wartości obserwacji w okresie K (w niniejszej analizie -6 miesięcy) w obie strony od danego punktu;

- wymuszeniu naprzemienności górnych i dolnych punktów zwrotnych, wybierając najwyższy spośród wielu górnych punktów zwrotnych i odpowiednio najniższy spośród wielu dolnych;

- eliminacji punktów zwrotnych zidentyfikowanych $\mathrm{w}$ okresie 6 miesięcy od początku i przed zakończeniem szeregu czasowego;

- eliminacji takich punktów zwrotnych, które są niższe (w przypadku górnych punktów zwrotnych) lub wyższe (w przypadku dolnych punktów zwrotnych) od wartości bliższych końca;

- eliminacji cykli i faz, które są krótsze niż odpowiednio wybrane, minimalne długości cyklu i faz.

Identyfikacja punktów zwrotnych pozwala na: wyodrębnienie cykli koniunkturalnych, obliczenie długości każdego, poszczególnego cyklu oraz średniej długości cykli, a wewnątrz cyklu - na określenie długości trwania fazy wzrostowej oraz spadkowej, a także przeciętnej długości trwania tych faz w całym szeregu.

Dla wahań odchyleń obliczono współczynniki korelacji krzyżowych $z$ opóźnieniami lub wyprzedzeniami względem cykli referencyjnych do 12 miesięcy (tabela 1 . oraz tabela 2.).

\section{Wyniki badania}

Na wykresie 1. przedstawiono cykle klasyczne PKB w strefie euro, Słowenii, Chorwacji, Serbii i Macedonii w latach 1995-2017. W analizowanym okresie w strefie euro zaobserwowano tylko jeden, pełny cykl klasyczny trwający od III kwartału 2009 roku do I kwartału 2013 roku. Od jego zakończenia trwała faza wzrostowa. Poprzedzająca cykl recesja trwała od II kwartału 2008 roku i była odzwierciedleniem kryzysu globalnego. Recesja w ramach cyklu, trwająca od III kwartału 2011 roku, była spowodowana kryzysem zadłużeniowym Grecji $\mathrm{i}$ innych państw peryferyjnych strefy euro.

W Słowenii, $w$ analizowanym okresie, również zaobserwowano jeden pełny cykl koniunkturalny, zsynchronizowany $z \quad c y-$ klem w strefie euro. Trzeba jednak zauważyć, że kryzys globalny zaczął oddziaływać na Słowenię o kwartal później niż w strefie euro, tj. w III kwartale 2008 roku.

W Chorwacji, w latach 2000-2017, nie wykryto żadnego, pełnego cyklu koniunkturalnego. Było to związane $z$ tym, że między kryzysem globalnym a "greckim” nie było okresu wzrostowego. Kryzys globalny rozpoczął się podobnie, jak w przypadku Słowenii, o kwartał później niż w strefie euro. Faza wzrostowa rozpoczęła się dopiero w II kwartale 2014 roku, o rok później niż w szeregu referencyjnym.

Większą zmiennością cechowała się koniunktura Serbii. W ujęciu klasycznym, zaobserwowano cztery pełne cykle. Pierwszy był zapewne powiązany $z$ wojnami jugosłowiańskimi. Jego początek przypadł na podpisanie porozumienia kończącego wojnę $\mathrm{w}$ Bośni i Hercegowinie, zaś jego koniec - na interwencję Organizacji Traktatu Północnoatlantyckiego (North Atlantic Treaty Organization, NATO) w konflikcie kosowskim. Kolejny cykl trwał od II kwartału 1999 roku do IV kwartału 2009 roku. Jego górny i dolny punkt zwrotny były opóźnione względem strefy euro o kwartał. Górny punkt zwrotny trzeciego cyklu miał miejsce w III kwartale 2011 roku, o kwartał później niż w strefie euro. Recesja zakończyła się pół roku wcześniej - w III 
kwartale 2012 roku. Ostatnie punkty zwrotne wystąpiły odpowiednio w III kwartale 2013 roku i IV kwartale 2014 roku i nie miały odpowiedników w strefie euro.

Dwa pełne cykle zaobserwowano w Macedonii. Pierwszy rozpoczął się po zakończeniu recesji spowodowanej wojną w Kosowie i kryzysem migracyjnym oraz etnicznymi napięciami w I kwartale 2002 roku, górny punkt zwrotny miał miejsce w III kwartale 2008 roku - pół roku po strefie euro. Recesja trwała rok. Górny punkt zwrotny przypadł na koniec 2016 roku. Recesja trwała tym razem pół roku.

$\mathrm{Na}$ wykresie 2. przedstawiono cykle odchyleń PKB w strefie euro, Słowenii, Chorwacji, Serbii i Macedonii w latach 1995-2017. W strefie euro zaobserwowano pięć pełnych cykli odchyleń PKB od trendu długookresowego. Pierwszy rozpoczął się w II kwartale 1997 roku. Górny punkt zwrotny miał miejsce na końcu tego samego roku, a dolny — rok później. Cykl ten prawdopodobnie był związany z koniunkturą w Azji Wschodniej i Rosji. Faza wzrostowa kolejnego cyklu zakończyła się w I kwartale 2001 roku. Recesja trwała do III kwartału 2003 roku. Była to tzw. bańka internetowa (dot-com boom). W trzecim cyklu odchyleń PKB strefy euro, wzrost i recesja trwały po trzy kwartały. Górny i dolny punkt zwrotny cyklu czwartego i piątego były takie same, jak w przypadku cykli klasycznych.

W Słowenii odnotowano pięć cykli odchyleń PKB. Pierwszy rozpoczął się trzy kwartały wcześniej niż w strefie euro, w III kwartale 1996 roku. Górny punkt zwrotny przypadł na II kwartał 1997 roku, gdy faza wzrostowa w strefie euro dopiero się rozpoczynała. Recesja zakończyła się o kwartał wcześniej niż w strefie euro, w III kwartale 1998 roku. Górny punkt zwrotny drugiego cyklu miał miejsce o pół roku wcześniej niż w strefie euro, a recesja trwała aż do końca 2004 roku, pomijając tym samym jeden krótki cykl strefy euro. Koniec fazy wzrostowej w 2008 roku nastąpił o kwartał wcześniej niż w strefie euro, dalszy przebieg kryzysu finansowego i zadłużeniowego przebiegał identycznie. Słowenia miała również pięć kwartałów recesji w latach
2014-2015, niemających odzwierciedlenia w koniunkturze europejskiej.

Cztery cykle odnotowano w Chorwacji. Kryzys światowy rozpoczął się i zakończył o kwartał później niż w strefie euro. Recesja, w wyniku kryzysu greckiego, zaczęła się o kwartał wcześniej, a zakończyła się o kwartał później. Chorwacja doświadczyła też własnej recesji w latach 2013-2014.

Siedem pełnych cykli zaobserwowano w Serbii. Dopiero od końca 2006 roku można zaobserwować spójność z koniunkturą strefy euro. Wówczas zaczęła się faza wzrostowa, zakończona na początku 2008 roku. Kryzys gospodarczy zakończył się o kwartał później niż w cyklu referencyjnym. Skutki kryzysu greckiego trwały trzy kwartały krócej. W latach 2013-2014 trwała kolejna recesja.

Trzy pełne cykle miały miejsce w Macedonii. Pierwszy, niezsynchronizowany ze strefą euro, trwał od początku 2002 roku do końca 2006 roku. Faza wzrostowa kolejnego cyklu zakończyła się w II kwartale 2008 roku. Faza spadkowa była zsynchronizowana z szeregiem referencyjnym. Kryzys grecki rozpoczął się trzy kwartały wcześniej, zakończył się o pół roku wcześniej. Od II kwartału 2016 roku w Macedonii trwała recesja.

W tabeli 1. przedstawiono korelacje krzyżowe PKB. Najwyższy poziom współczynnika korelacji równoległej odchyleń odnotowano w Słowenii, wyniósł on 0,8986 . W przypadku Macedonii, najlepiej z koniunkturą strefy euro korelowały odchylenia równoległe, ale współczynnik korelacji wyniósł tylko 0,4428. Dla Chorwacji, najwyższy poziom współczynnika korelacji odnotowano dla opóźnienia o jeden kwartał, dla Serbii - o pół roku. Współczynnik ten jednak był bardzo niski i wynosił 0,3294 .

$\mathrm{Na}$ wykresie 3. przedstawiono cykle klasyczne produkcji przemysłowej $\mathrm{w}$ strefie euro, Słowenii, Chorwacji, Serbii i Macedonii w latach 1998-2017. W strefie euro zaobserwowano pięć pełnych cykli produkcji przemysłowej. Pomijając pierwszy cykl, którego $z$ racji braku danych, nie można porównać do państw byłej Jugosławii, recesja $w$ drugim cyklu, pod wpływem kryzysu azjatyckiego, trwała od 
lipca 1998 roku do końca tego roku. Kolejna recesja to tzw. bańka internetowa trwająca od początku 2001 roku do stycznia 2002 roku. Światowy kryzys zaczął wpływać na produkcję przemysłową w lutym 2008 roku. Wówczas dolny punkt zwrotny odnotowano w czerwcu 2009 roku. Po dwóch latach rozpoczął się kryzys zadłużeniowy, zakończony dolnym punktem zwrotnym w styczniu 2013 roku.

W Słowenii odnotowano dwa cykle klasyczne produkcji przemysłowej. Pierwszy rozpoczą się po zakończeniu kryzysu azjatyckiego w marcu 1999 roku (3 miesiące po strefie euro). Faza wzrostowa zakończyła się w marcu 2008 roku, 2 miesiące po strefie euro. Koniec cyklu był zsynchronizowany. Faza wzrostowa drugiego cyklu zakończyła się w styczniu 2011 roku, a recesja się zakończyła 5 miesięcy po strefie euro, w czerwcu 2013 roku.

W Chorwacji miał miejsce jeden cykl klasyczny, początek którego (górny punkt zwrotny) zbiegł się z początkiem słoweńskiego cyklu w 1999 roku i odpowiednio punktem zwrotnym w 2008 roku. Recesja trwała do października 2013 roku, 9 miesięcy dłużej niż w strefie euro.

W Serbii zaobserwowano cztery cykle. Faza spadkowa pierwszego cyklu w latach 2002-2003, nie miała podobieństw do koniunktury strefy euro. Recesja w 2008 roku zaczęła się 3 miesiące po strefie euro, a zakończyła się miesiąc wcześniej. W Serbii kryzys grecki był odczuwalny 2 miesiące przed strefą euro, ale faza spadkowa zakończyła się $10 \mathrm{mie}$ sięcy wcześniej. Recesja lat 2013-2014 również nie miała odpowiedników w strefie euro.

Trzy cykle zaobserwowano w Macedonii. Faza spadkowa pierwszego cyklu w latach 2003-2005, nie miała odpowiedników w strefie euro. Kryzys światowy rozpoczął się w czerwcu 2008 roku, 4 miesiące po strefie euro, recesja trwała do maja 2010 roku. Kryzys grecki rozpoczął się w tym samym momencie, a zakończył się 10 miesięcy wcześniej. Od marca 2016 roku trwała kolejna recesja.

$\mathrm{Na}$ wykresie 4. przedstawiono cykle odchyleń produkcji przemysłowej w strefie euro, Słowenii, Chorwacji, Serbii i Macedonii w latach 1998-2017. Osiem cykli koniunktural- nych zaobserwowano w strefie euro. Kryzys azjatycki w tym ujęciu trwał przez rok: od marca 1998 roku. Tzw. bańka internetowa rozpoczęła się w grudniu 2000 roku i trwała do lipca 2003 roku. W lipcu 2004 roku rozpoczęła się kolejna recesja trwająca 7 miesięcy. Przebieg kryzysu finansowego był podobny do ujęcia klasycznego, kryzys grecki trwał o kwartał dłużej. W 2014 roku i w latach 2015-2016 wystąifily krótkie fazy spadkowe.

Trzy cykle odnotowano w Słowenii. Tzw. bańka internetowa rozpoczęła się miesiąc później niż w przypadku szeregu referencyjnego, ale zakończyła się dopiero w grudniu 2004 roku, 2 miesiące przed końcem, już drugiej w tym okresie, recesji w strefie euro. Kryzys finansowy rozpoczął się 3 miesiące po strefie euro, a zakończył się w tym samym okresie. Kryzys grecki zaczął się 2 miesiące wcześniej, ale trwał aż do marca 2014 roku.

Cztery cykle miały miejsce w Chorwacji. W latach 2001-2002 trwała faza wzrostowa, niezaobserwowana $w$ strefie euro. Kryzys światowy został przesunięty o 3 miesiące względem strefy euro. Kryzys grecki rozpoczął się 2 miesiące później. Recesja trwała do września 2013 roku. Od stycznia 2017 roku Chorwacja znajdowała się $\mathrm{w}$ kolejnej fazie spadkowej.

Sześć cykli zaobserwowano w Serbii. Recesja lat 2002-2003 była znacznie krótsza niż odpowiednia faza spadkowa strefy euro. Kryzys lat 2004-2005, choć o kwartał dłuższy, był dobrze zsynchronizowany z koniunkturą strefy euro. Oddziaływanie kryzysu światowego rozpoczęło się 2 miesiące później, a zakończyło się miesiąc wcześniej. Recesja w latach 2011-2012 była krótsza niż w strefie euro, ale kolejna rozpoczęła się już we wrześniu 2013 roku, 4 miesiące wcześniej niż w strefie euro.

Pięć cykli odnotowano w Macedonii. Warto zauważyć, że fazy spadkowe w latach 2003-2004 i 2005 roku oraz 2014 roku nie miały odpowiedników w strefie euro. Światowy kryzys zaczął oddziaływać na Macedonię 4 miesiące po strefie euro, dolny punkt zwrotny - 11 miesięcy później. Kryzys grecki zaczął oddziaływać podobnie, jak w strefie 
euro, ale dolny punkt zwrotny miał miejsce w sierpniu 2012 roku. Od początku 2016 roku Macedonia znajdowała się $\mathrm{w}$ recesji.

W tabeli 2. przedstawiono korelacje krzyżowe produkcji przemysłowej. Najwyższy poziom współczynnika korelacji równoległej wyniósł 0,9335 i był odnotowany dla cykli odchyleń w Słowenii i strefie euro. Jeszcze wyższy poziom współczynnika odnotowano dla opóźnienia o miesiąc. Poziom współczynnika korelacji równoległej dla Serbii wyniósł 0,7615. Dla Chorwacji i Macedonii najwyższy jego poziom zaobserwowano dla opóźnień o 3 miesiące.

\section{Zakończenie}

Analiza morfologiczna otrzymanych cykli koniunkturalnych pozwala na wyciągnięcie kilku podstawowych wniosków. Poprawiła się zbieżność cykli koniunkturalnych $w$ kategoriach $\mathrm{PKB}$ oraz produkcji przemysłowej $\mathrm{w}$ czterech analizowanych państwach od rozpoczęcia globalnego kryzysu finansowego. Opóźnienia lub wyprzedzenia punktów zwrotnych względem cyklu referencyjnego generalnie się zmniejszyły. Nie oznacza to jednak, że nie wystąiły cykle dodatkowe.

Powyższe wyniki oznaczają, że gospodarka Słowenii, już będącej w strefie euro, jest dobrze zsynchronizowana $z$ gospodarką całej strefy i powinna odczuć skutki polityki pieniężnej Europejskiego Banku Centralnego (EBC) podobnie, jak inne państwa strefy euro. Koniunktura pozostałych, analizowanych państw wykazywała znacznie gorsze ich przygotowanie do wejścia do strefy euro. Problemem Chorwacji jest słaba synchronizacja w kategorii produkcji przemysłowej. W przypadku Serbii i Macedonii wykazano dość słabą synchronizację $\mathrm{w}$ każdej kategorii, zwłaszcza $\mathrm{PKB}$, na co wskazywał niższy poziom współczynnika korelacji oraz dodatkowe cykle koniunkturalne. Dalsza integracja tych gospodarek jest niezbędna przed zmianą waluty.

\section{Bibliografia}

Adamowicz, E., Dudek, S., Pachucki, D., i Walczyk, K. (2012). Wahania cykliczne w Polsce i strefie euro. Prace i materialy Instytutu Rozwoju Gospodarczego SGH. Warszawa: SGH.

Artis, M., Krolzig, H., i Toro, J. (2004). The European business cycle. Oxford Economic Papers, 56(1). doi:10.1093/oep/56.1.1.

Burns, A.F., i Mitchell, W.C. (red.). (1946). Measuring business cycles. Cambridge: NBER.

Canova, F., i Schlaepfer, A. (2015). Has the Euro-mediterranean partnership affected mediterranean business cycles? Journal of Applied Econometrics, 30(2). doi:10.1002/jae.2364.

Darvas, Z., i Szapáry, G. (2008). Business cycle synchronization in the enlarged EU. Open Economies Review, 19(1). doi:10.1007/ s11079-007-9027-7.

de Haan, J., Inklaar, R., i Jong-A-Pin, R. (2008). Will business cycles in the euro area converge? A critical survey of empirical research. Journal of Economic Surveys, 22(2). doi:10.1111/j.1467-6419.2007.00529.x.

Eurostat. (2018). Pobrane 20.05.2018 z http:// ec.europa.eu/eurostat.

Frankel, J.A., i Rose, A.K. (1998). The endogeneity of the optimum currency area criteria. The Economic Journal, 108(449). doi:10.1111/1468-0297.00327.

Giannone, D., Lenza, M., i Reichlin, L. (2009). Business cycles in the euro area. European Central Bank Working Paper Series, 1010.

Gogas, P. (2013). Business cycle synchronisation in the European Union: the effect of the common currency. OECD Journal of Business Cycle Measurement and Analysis, 1. doi:10.1787/ jbcma-2013-5k43jt540lzs.

Jiménez-Rodríguez, R., Morales-Zumaquero, A., i Égert, B. (2013). Business cycle synchronization between euro area and Central and Eastern European countries. Review of Development Economics, 17 (2). doi:10.1111/rode.12038.

Maravall, A., i del Rio, A. (2001). Time aggregation and the Hodrick-Prescott filter. Banco de Espana Working Papers, 108.

Mintz, I. (red.). (1970). Dating postwar business cycles: methods and their application to Western Germany, 1950-1967. Cambridge: NBER.

Mundell, R.A. (1961). A theory of optimum currency areas. American Economic Review, 51(4). 
Nillson, R., i Gyomai, G. (2011). Cycle extraction: a comparison of the phase-average trend method, the Hodrick-Prescott and ChristianoFitzgerald filters. OECD Statistics Working Papers, 04. doi: $10.1787 / 5 \mathrm{~kg} 9$ srt 7 f8g0-en.

Obradović, S., i Mihajlović V. (2013). Synchronization of business cycles in the selected European countries. Panoeconomicus, 60(6). doi:10.2298/ pan1306759o.

Seymen, A. (2012). Euro area business cycles. OECD Journal of Business Cycle Measurement and Analysis, 1. doi:10.1787/jbcma-2012-5k98xgf7dnwk.

Traktat o Unii Europejskiej (OJ C 326, 26.10.2012).

Yamada, H. (2011). A note on band-pass filters based on the Hodrick-Prescott filter and the OECD system of composite leading indicators. OECD Journal of Business Cycle Measurement and Analysis, 2. doi:10.1787/jbcma-2011-5kg0pb01sbbt.
Informacje uzupetniające

Wkład autorski: autor zaakceptował ostateczną wersję artykułu.

Źródła finansowania: artykuł został w całości sfinansowany ze środków własnych autora.

Uwagi: wyniki badania były zaprezentowane na VIII Ogólnopolskiej Konferencji Naukowej z cyklu Problemy gospodarki światowej (Toruń, 20.04.2018). 
Aneks

Tabela 1.

Korelacje krzyżowe PKB

\begin{tabular}{lccc}
\hline \multicolumn{1}{c}{ Państwo } & $r$ & $r_{\text {max }}$ & $t_{\text {max }}$ \\
\hline Chorwacja & $0,8223(0,0000)$ & $0,8412(0,0000)$ & 1 \\
Stowenia & $0,8986(0,0000)$ & $0,8986(0,0000)$ & 0 \\
Macedonia & $0,4428(0,0001)$ & $0,4428(0,0001)$ & 0 \\
Serbia & $0,2350(0,0241)$ & $0,3294(0,0150)$ & 2 \\
\hline
\end{tabular}

Uwagi:

$r$ - wspótczynnik korelacji jednoczesnych;

$r_{\max }$ - największy współczynnik korelacji;

$t_{\text {max }}$ - opóźnienie dla największego wspótczynnika korelacji.

$\mathrm{W}$ nawiasie podano empiryczny poziom istotności.

Żródło: Opracowanie własne na podstawie Eurostat (2018).

Tabela 2.

Korelacje krzyżowe produkcji przemysłowej

\begin{tabular}{lccc}
\hline \multicolumn{1}{c}{ Państwo } & $r$ & $r_{\max }$ & $t_{\text {max }}$ \\
\hline Chorwacja & $0,6264(0,0000)$ & $0,6710(0,0000)$ & 3 \\
Stowenia & $0,9335(0,0000)$ & $0,9418(0,0000)$ & 1 \\
Macedonia & $0,6654(0,0000)$ & $0,7089(0,0000)$ & 3 \\
Serbia & $0,7615(0,0000)$ & $0,7615(0,0000)$ & 0 \\
\hline
\end{tabular}

Uwagi:

$r$ - współczynnik korelacji jednoczesnych;

$r_{\max }$ - największy współczynnik korelacji;

$t_{\text {max }}$ - opóźnienie dla największego współczynnika korelacji.

W nawiasie podano empiryczny poziom istotności.

Źródło: Opracowanie własne na podstawie Eurostat (2018). 
Wykres 1.

Cykle klasyczne PKB w strefie euro, Słowenii, Chorwacji, Serbii i Macedonii w latach 1995-2017 (2010=100)

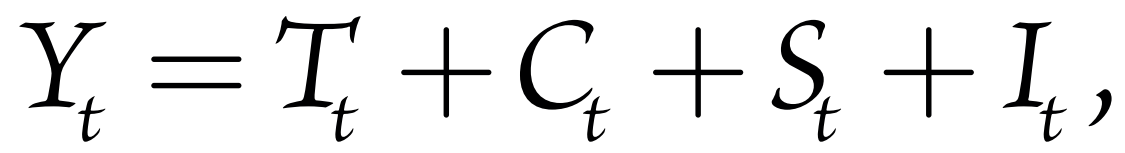

Źródło: Opracowanie własne na podstawie danych Eurostat (2018).

Wykres 2.

Cykle odchyleń PKB w strefie euro, Słowenii, Chorwacji, Serbii i Macedonii w latach 1995-2017 (w \% odchylenia od trendu)

$$
\min _{\tau_{t}}\left[\sum_{t=1}^{T}\left(Y_{t}-\tau_{t}\right)^{2}+\tau_{t=2}^{T-1}\left[\left(\tau_{t+1}-\tau_{t}\right)-\left(\tau_{t}-\tau_{t-1}\right)\right]^{2}\right] .
$$


Wykres 3.

Cykle klasyczne produkcji przemysłowej w strefie euro, Słowenii, Chorwacji, Serbii i Macedonii w latach $1998-2017(2010=100)$

$\min _{C_{t}}\left[\sum_{t=1}^{T}\left[\left(C_{t}+I_{t}\right)-C_{t}\right]^{2}+\right.$

Żródło: Opracowanie własne na podstawie danych Eurostat (2018).

Wykres 4.

Cykle odchyleń produkcji przemysłowej w strefie euro, Słowenii, Chorwacji, Serbii i Macedonii w latach 1998-2017 (w \% odchylenia od trendu)

$\lambda=\left[4\left[1-\cos \left(\omega_{0}\right)\right]^{2}\right]^{-1}$ 
Synchronization of business cycles of selected countries of former Yugoslavia with the euro area

\section{Abstract}

Motivation: R. Mundell's optimal currency area theory stipulates that for countries joining a currency area must achieve business cycle synchronization with the area. This criterion is not formally required for the euro area, so is often omitted in the analysis of preparation of the particular European Union (EU) countries to join the euro area.

Aim: The aim of this article is to analyze the degree of business cycle synchronization of four countries of the former Yugoslavia with the euro area. The former Yugoslavia countries are on different stages of European integration and convergence with the EU economy, so the degree of synchronization of business cycles between countries is also different.

Materials and methods: In this article, the time series of GDP and industrial production of the euro area and four countries of the former Yugoslavia (Slovenia, Croatia, Serbia and Macedonia) were used. They were decomposed into trend and cyclical component using the Hodrick-Prescott filter twice. Afterwards, the classical and the deviation cycles were obtained and turning points were identified, which were the basis for the analysis of cycle synchronization.

Results: Among the analyzed countries of the former Yugoslavia, the Slovenian economy is well-synchronized with the economy of the euro area. In the case of Croatia, there was a poor synchronization in the industrial production category. In the case of Serbia and Macedonia, there was quite a weak synchronization in each category, especially GDP, which was indicated by a lower level of correlation coefficient and additional business cycles.

Keywords: euro area; business cycles; synchronization, Balkan region JEL: E32; F02 
